\title{
Pengaruh Penambahan Berbagai Konsentrasi L-Ascorbic Acid Terhadap Kemampuan Migrasi Adipose-Derived Stem Cells Asal Manusia
}

\author{
Karina Karina ${ }^{1,2}$, Imam Rosadi ${ }^{1}$, Wismo Reja Subroto ${ }^{1}$, Alfida Zakiyah ${ }^{1}$, Irsyah Afini ${ }^{1}$, Iis Rosliana $^{1}$, \\ Tias Widyastuti ${ }^{1}$, Siti Sobariah ${ }^{1}$
}

${ }^{1}$ Hayandra Lab, Yayasan Hayandra Peduli, Jl. Kramat 6, Jakarta Pusat, 10430

${ }^{2}$ Klinik Hayandra, Yayasan Hayandra Peduli, Jl. Kramat 6, Jakarta Pusat, 10430

Penulis untuk Korespondensi/E-mail: wismo.rs@ hayandra.com

\begin{abstract}
Abstrak - Mesenchymal Stem Cells (MSCs) merupakan sel yang memiliki kemampuan memperbarui diri dan berdiferensiasi menjadi berbagai jenis sel. MSCs berperan penting dalam perbaikan dan regenerasi jaringan. Adipose-Derived Stem Cells (ADSCs) merupakan MSCs yang didapatkan dari jaringan lemak. ADSCs telah banyak digunakan dalam studi MSCs karena ketersediaan sumber sel yang banyak dalam jaringan tubuh dan proses isolasinya lebih mudah serta memiliki risiko yang lebih rendah. Pada studi ini, ADSCs digunakan untuk mengetahui kemampuan migrasi dalam medium yang mengandung fetal bovine serum 10\% (FBS) dengan penambahan $L$-Ascorbic Acid (LAA) konsentrasi $0 \%, 1 \%, 3 \%$ dan $6 \%$. Kuantifikasi kemampuan migrasi dilakukan dengan menggunakan teknik goresan luka. ADSCs yang dikulturkan menunjukkan morfologi seperti fibroblas. Luas penutupan luka menunjukkan hasil tertinggi dengan perbedaan yang tidak signifikan pada penambahan konsentrasi LAA 3\% dan 6\% dibandingkan penambahan LAA $0 \%, 1 \%$ dan kontrol. Hasil ini juga ditunjukkan pada pasase 7, 8, dan 9. ADSCs menunjukkan kemampuan migrasi yang optimal pada penambahan LAA 3\% dan $6 \%$ dibandingkan medium dengan penambahan LAA $0 \%, 1 \%$ dan kontrol.
\end{abstract}

Abstract - Mesenchymal stem cells (MSCs) are multilineage cells with the ability to self-renew and differentiate into a variety of cell types. MSCs play important role in tissue repair and regeneration. Adipose-Derived Stem Cells (ADSCs) are MSCs derived from fat tissue. ADSCs has been widely used in MSCs studies because it require more cell sources in body tissue and the process of isolation is easier and has lower risk. In this study, ADSCs were used to determine migration ability in a medium containing $10 \%$ bovine fetal serum (FBS) using $0 \%, 1 \%, 3 \%$ and $6 \%$ of L-Ascorbic Acid (LAA) concentrations. Quantification of migration ability was done by using scratch technique. ADSCs were cultured display fibroblasts-like morphology. The closure of wound area is highest with not significantly difference in LAA concentrations of $3 \%$ and $6 \%$ compared to LAA $0 \%, 1 \%$ and control. This results were also showed on 7, 8, and 9 cell passage. ADSCs showed optimal migration ability at LAA 3\% and $6 \%$ compared to media with LAA $0 \%, 1 \%$ and control.

Keywords - ADSCs, Cells Migration, LAA.

\section{PENDAHULUAN}

Sel punca adalah sel yang memiliki kemampuan Smemperbarui diri dan berdiferensiasi menjadi berbagai jenis sel [1,2]. Dengan kemampuan tersebut, sel punca memainkan peran penting dalam regenerasi jaringan untuk penyakit degeneratif $[3,4]$. Sel punca dapat tinggal (homing) dan bermigrasi ke jaringan yang terluka. Sel punca berdiferensiasi pada jaringan yang terluka dan memiliki kemampuan untuk mensekresikan kemokin, sitokin, faktor inflamasi, berbagai protein matriks ekstraseluler dan faktor pertumbuhan lainnya yang membantu proses regenerasi jaringan $[5,6]$. Sel punca dapat diperoleh dari jaringan embrionik dan jaringan dewasa. Penggunaan sel punca dari jaringan dewasa lebih aman dan lebih banyak digunakan dibandingkan dengan sel punca dari jaringan embrionik. Sel punca yang berasal dari jaringan dewasa antara lain ditemukan pada 
jaringan saraf, tali pusat (Umbilical Cord), sumsum tulang (Bone Marrow Stem Cells/BMSCs) dan jaringan lemak (Adipose Derived Stem Cells/ADSC $\mathrm{S}_{\mathrm{S}}[\mathrm{7}, 8,9]$.

$\mathrm{ADSC}_{\mathrm{S}}$ memiliki sifat yang hampir sama dengan BMSCs yang telah banyak dilaporkan. ADSCs memiliki sumber sel lebih banyak di dalam jaringan tubuh bila dibandingkan dengan $\mathrm{BMSC}_{\mathrm{S}}$. Sehingga, $\mathrm{ADSC}_{\mathrm{S}}$ dapat diperoleh dalam jumlah yang lebih tinggi [10]. Selain itu, proses isolasi ADSCs lebih mudah dan memiliki risiko lebih rendah dibandingan dengan BMSCs [11]. Ascorbic Acid-2phosphate/L-Ascorbic Acid (LAA) telah dikenal sebagai antioksidan yang dapat menangkal radikal bebas pada tingkat seluler. LAA sering digunakan sebagai suplemen media kultur sel untuk mengatur konsentrasi Reactive Oxygen Species (ROS) dan menjaga pertumbuhan sel [12]. LAA dilaporkan dapat mendukung proliferasi, diferensiasi dan menekan penuaan sel [13]. Penambahan LAA pada medium Fetal Bovine Serum (FBS) juga telah dilaporkan memiliki laju migrasi ADSCs lebih tinggi dibandingkan medium tanpa penambahan LAA [14].

Tujuan dari studi ini adalah untuk mengetahui kemampuan migrasi $\mathrm{ADSC}_{\mathrm{S}}$ secara in vitro pada medium pertumbuhan sel dengan penambahan berbagai konsentrasi LAA. Teknik yang digunakan untuk melihat kemampuan migrasi sel adalah teknik goresan luka [15]. Teknik ini bertujuan untuk menunjukkan persentase penutupan luka oleh proses migrasi sel. Perlakuan penambahan berbagai konsentrasi LAA dalam medium pertumbuhan dilakukan pada pasase sel yang berbeda sehingga dapat menunjukkan pengaruh konsentrasi LAA terhadap kemampuan migrasi ADSCs seiring dengan penambahan pasase sel.

\section{METODE}

\section{Isolasi dan Kondisi Kultur ADSCs}

ADSCs diisolasi dari jaringan lemak manusia. Isolasi ADSCs tersebut menggunakan teknik enzimatis mengacu pada protokol H-Remedy dari Yayasan Hayandra Peduli (Nomor Paten: IDP000055609) [16]. Sampel lemak ditambahkan enzim H-Remedy sebanyak $10 \%$ lalu diinkubasi pada suhu $37^{\circ} \mathrm{C}, 300 \mathrm{rpm}$, selama 60 menit. Enzim kemudian diinaktivasi dengan penambahan medium Dulbecco's Modified Eagle's (DMEM) rendah glukosa (1 $\mathrm{g} / \mathrm{L})$ yang mengandung Lglutamin (4 mM) (Gibco, USA) dan disentrifugasi pada kecepatan $600 \mathrm{~g}$ selama 5 menit. Supernatan yang terbentuk pada lapisan bagian atas kemudian dibuang dan disentrifugasi kembali pada kecepatan 600 g selama 5 menit.

Pelet sel yang mengandung ADSCs kemudian dikultur menggunakan medium pertumbuhan DMEM yang mengandung $1 \%$ antibioticantimycotic (ABAM) 100X (Gibco, USA) dan 10\% Fetal Bovine Serum (FBS) (Gibco, USA) pada suhu $37^{\circ} \mathrm{C}, 5 \% \mathrm{CO} 2$. ADSCs dikultur dan diremajakan hingga pasase 6 (P6) dengan penggantian medium setiap 3-4 hari sekali. ADSCs kemudian digunakan untuk uji migrasi sel pada pasase 7 , pasase 8 , dan pasase $9(\mathrm{P} 7, \mathrm{P} 8, \mathrm{P} 9)$.

\section{Medium Kelompok Perlakuan ADSCs}

Sebanyak $1 \times 10^{4}$ dikultur pada 24 well-plate dalam berbagai medium pertumbuhan yaitu:

a. DMEM (Gibco,USA) sebagai medium kontrol

b. DMEM (Gibco,USA) + 10\% FBS (Biowest, USA) + 1\% ABAM (Biowest,USA)

c. DMEM (Gibco,USA) + 10\% FBS (Biowest, USA) + $1 \%$ ABAM (Biowest, USA) + $1 \mathrm{mg} / \mathrm{mL}$ LAA (Sigma,USA)

d. DMEM (Gibco,USA) + 10\% FBS (Biowest, USA) + $1 \%$ ABAM (Biowest, USA) + 3 $\mathrm{mg} / \mathrm{mL}$ LAA (Sigma,USA)

e. DMEM (Gibco,USA) + 10\% FBS (Biowest, USA) + 1\% ABAM (Biowest, USA) + 6 $\mathrm{mg} / \mathrm{mL}$ LAA (Sigma,USA)

Sel diamati pertumbuhannya hingga mencapai konfluensi lebih dari $90 \%$ dan dilanjutkan uji migrasi dengan teknik goresan luka.

\section{Uji Migrasi ADSCs}

ADSCs yang telah dikultur pada berbagai medium pertumbuhan lalu dibuat goresan sebanyak 1 kali goresan (luka) pada well menggunakan tips $200 \mu \mathrm{l}$ steril (Gen Follower). Posisi ujung tips berada di ujung atas well, penggoresan dilakukan secara vertikal. Prosedur penggoresan dilakukan sama pada setiap kelompok perlakuan dengan berbagai medium pertumbuhan. Sel kemudian dicuci menggunakan Phosphate Buffered Saline (PBS) (Lonza, USA) untuk membersihkan debris atau selsel yang mati akibat goresan. Sel lalu dikultur menggunakan kelompok lima variasi medium pertumbuhan.

\section{Pengambilan Gambar dan Analisis Data}

Gambar pada jam ke-0 diambil setelah pembuatan goresan luka pada ADSCs sebagai data luas area awal ADSCs. Proses penutupan luka monolayer terhadap luas area migrasi sel diamati pada jam ke- 
$24(\mathrm{t}=\Delta \mathrm{h})$. Gambar diambil menggunakan mikroskop inverted fasa terbalik (OPTIKA, ITALY; objektif 4x) dengan kamera digital OPTIKA (OPTIKA, ITALY). Luas area luka dikuantifikasi menggunakan perangkat lunak imageJ (National Institutes of Health, USA). Migrasi sel terhadap penutupan luka dihasilkan dalam bentuk folding (kali lipat).

Rumus penutupan goresan atau luka pada ADSCs sebagai berikut:

\section{Penutupan Luka ADSCs $=\frac{\text { Luas Area } \Delta h}{\text { Luas Area } 0 h}$}

Keterangan:

- Luas Area $\Delta h$ adalah luas area yang diukur setelah dilakukan goresan pada jam ke-24;

- Luas Area $0 h$ adalah luas area yang diukur setelah dilakukan goresan pada jam ke-0.

\section{HASIL DAN PEMBAHASAN}

\section{Morfologi ADSCs}

Karakteristik ADSCs pada studi ini berbentuk seperti fibroblas dan menempel pada dasar substrat (cawan polystyrene) sesuai dengan konsensus standar dari salah satu ciri sel punca [17]. Metode goresan luka pada studi ini merupakan metode standar in vitro dalam mempelajari migrasi sel $[18,19]$. Metode ini menunjukkan proses kolonisasi kembali ADSCs yang telah dikultur dengan konfluensi pertumbuhan sel lebih dari 90\%. ADSCs yang dilukai (digores) akan membentuk daerah tanpa sel puncalfree-cell area (FCA) (Gambar 1). Pada studi ini, kuantifikasi migrasi sel didasarkan pada persentase ukuran luas penutupan luka dalam waktu inkubasi 24 jam [20].



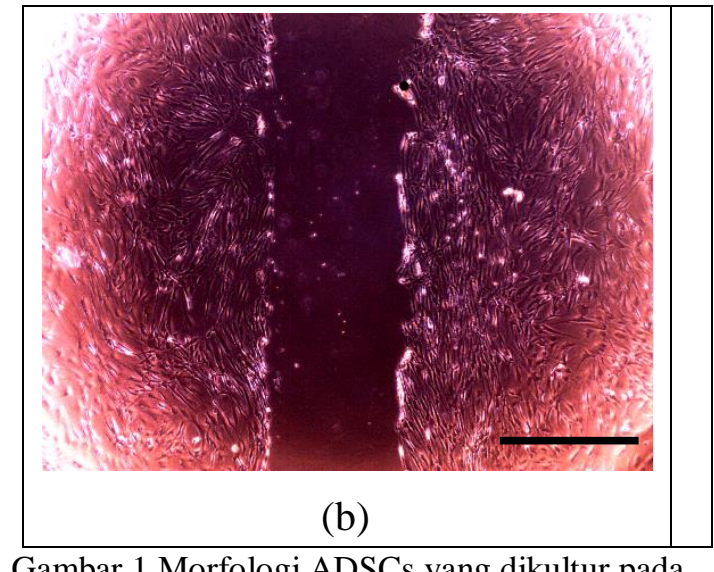

Gambar 1 Morfologi ADSCs yang dikultur pada polystyrene: (a) Konfluensi sel $>90 \%$; (b) Penampakan

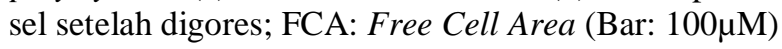

\section{Luas Penutupan Luka}

Luas goresan dan penutupan luas luka pada ADSCs P7, P8, dan P9 setiap perlakuan dalam beragam konsentrasi LAA ditunjukkan pada Gambar 2. Keragaman luas awal ini diduga dipengaruhi oleh posisi sel yang hor' 1 dan vertikal serta kekuatan penggoresan (b) ?enambahan frekuensi pembelahan sel dan peningkatan pasase dapat menyebabkan peningkatan penuaan sel (senesens sel). Peristiwa tersebut disebut Hayflick Phenomenon [22]. Meningkatnya penuaan sel dapat menyebabkan penurunan fungsi biologis sel terutama kemampuan migrasi ADSCs [23]. Secara morfologi sel, penambahan LAA pada medium pertumbuhan ADSCs dapat mengurangi tanda penuaan sel dibandingkan dengan ADSCs tanpa penambahan LAA [24]. Proses migrasi ADSCs ditunjukkan dengan adanya proses penutupan luka saat inkubasi ADSCs selama 24 jam. Migrasi ADSCs juga dapat dipengaruhi karena adanya respon sel terhadap lingkungan mikro eksternal [25].

Luas penutupan luka oleh ADSCs yang dikultur pada P7, P8 dan P9 menunjukkan konsistensi penutupan luka yang optimal pada perlakuan medium dengan penambahan LAA 3\%. Pada P7 dan $\mathrm{P9}$, proses penutupan luka oleh aktivitas migrasi menunjukkan penurunan luas luka seiring dengan peningkatan konsentrasi LAA berturutturut pada medium DMEM (blanko), DMFA, DMFAA 1\% dan DMFAA 3\% (Tabel 1). Proses penutupan luka oleh pertumbuhan ADSCs menunjukkan kemampuan migrasi [21]. Penutupan luka ini menunjukkan bahwa ADSCs yang dikultumonolayer bereaksi terhadap keberadaan luka dan menutupi luka tersebut [26]. Proses penutupan luka diinduksi oleh ADSCs yang terluka 
dengan cara produksi ROS dan kemokin (Gambar

4) [27].

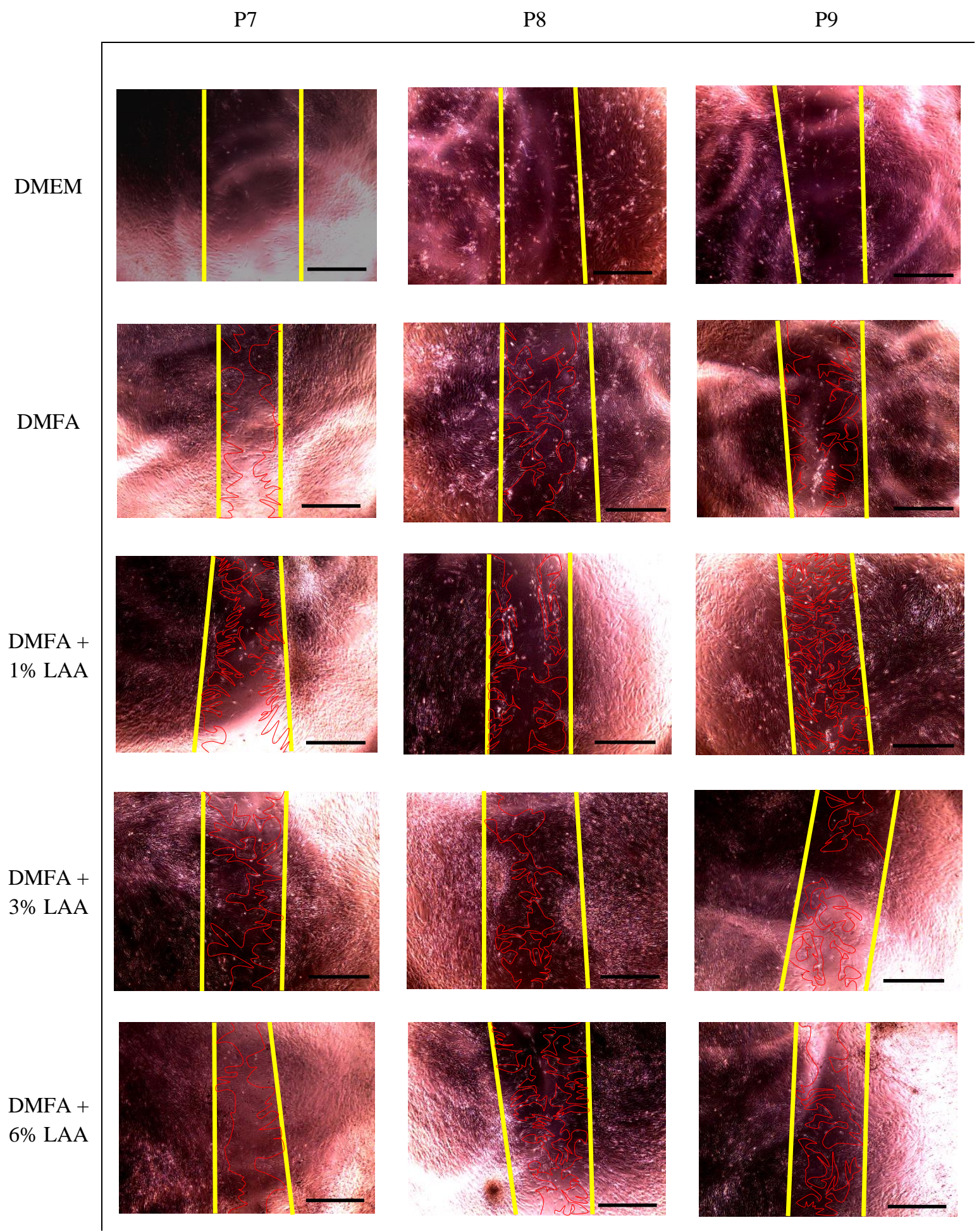

Gambar

2 Migrasi sel ADSCs P7, P8, dan P9 dalam medium pertumbuhan dengan penambahan berbagai konsentrasi LAA setelah

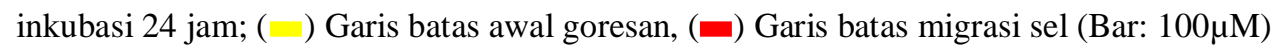


Tabel 1. Penutupan luka oleh ADSCs setelah di inkubasi 24 Jam dengan penambahan berbagai konsentrasi LAA

\begin{tabular}{|c|c|c|c|c|}
\hline \multirow{2}{*}{ Pasase } & \multirow{2}{*}{ Perlakuan } & \multicolumn{2}{|c|}{ Luas luka \pm SD $\left(\mathrm{mm}^{2}\right)$} & \multirow{2}{*}{$\begin{array}{c}\text { Folding } \\
\text { (kali lipat) }\end{array}$} \\
\hline & & Sebelum & Sesudah & \\
\hline \multirow{5}{*}{ P7 } & DMEM & $0,529 \pm 0,009$ & $0,075 \pm 0,041$ & 1,00 \\
\hline & DMFA & $0,297 \pm 0,014$ & $0,084 \pm 0,024$ & 1,19 \\
\hline & DMFAA $1 \%$ & $0,404 \pm 0,068$ & $0,146 \pm 0,039$ & 1,34 \\
\hline & DMFAA $3 \%$ & $0,394 \pm 0,027$ & $0,199 \pm 0,015$ & 1,72 \\
\hline & DMFAA $6 \%$ & $0,430 \pm 0,074$ & $0,211 \pm 0,023$ & 1,67 \\
\hline \multirow{5}{*}{ P8 } & DMEM & $0,356 \pm 0,003$ & $0,015 \pm 0,019$ & 1,00 \\
\hline & DMFA & $0,444 \pm 0,018$ & $0,168 \pm 0,032$ & 1,54 \\
\hline & DMFAA $1 \%$ & $0,413 \pm 0,027$ & $0,110 \pm 0,009$ & 1,31 \\
\hline & DMFAA $3 \%$ & $0,449 \pm 0,024$ & $0,292 \pm 0,020$ & 2,75 \\
\hline & DMFAA $6 \%$ & $0,505 \pm 0,028$ & $0,340 \pm 0,067$ & 2,93 \\
\hline \multirow{5}{*}{ P9 } & DMEM & $0,347 \pm 0,028$ & $0,040 \pm 0,027$ & 1,00 \\
\hline & DMFA & $0,351 \pm 0,016$ & $0,101 \pm 0,009$ & 1,24 \\
\hline & DMFAA $1 \%$ & $0,387 \pm 0,020$ & $0,155 \pm 0,016$ & 1,48 \\
\hline & DMFAA $3 \%$ & $0,418 \pm 0,069$ & $0,187 \pm 0,012$ & 1,60 \\
\hline & DMFAA $6 \%$ & $0,379 \pm 0,017$ & $0,133 \pm 0,078$ & 1,37 \\
\hline
\end{tabular}
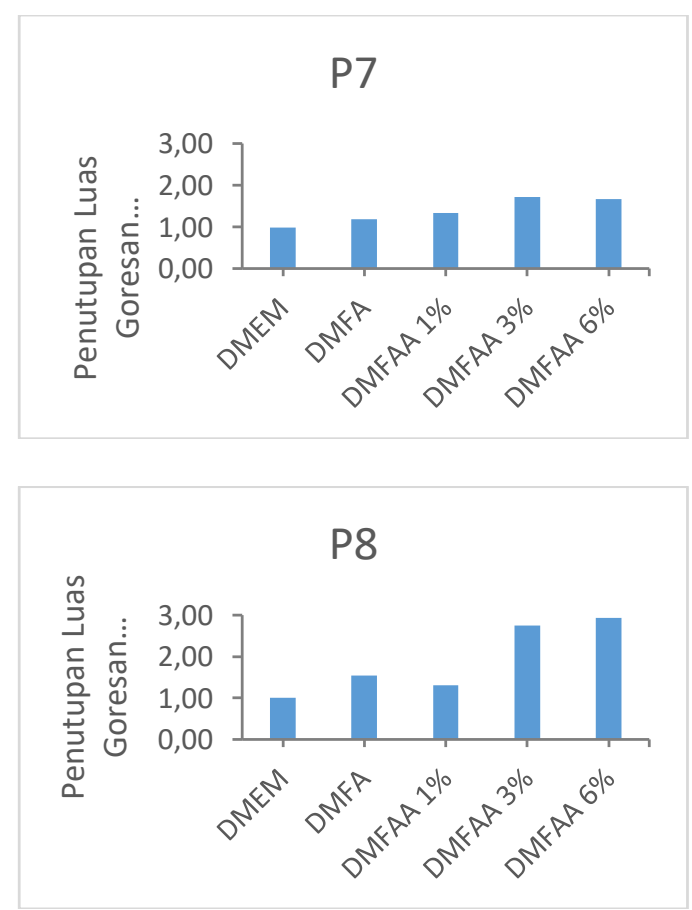



Gambar 3. Peningkatan penutupan luas luka dengan satuan "kali lipat" secara in vitro dengan penambahan berbagai konsentasi LAA dalam medium pertumbuhan setelah diinkubasi 24 jam

Tidak ada perbedaan signifikan antara perlakuan penambahan LAA 3\% dan LAA $6 \%$ pada medium kultur sel (Tabel 1). Namun, kedua perlakuan ini menunjukkan peningkatan yang optimal dibandingkan perlakuan kontrol (DMEM) dan perlakuan penambahan konsentrasi LAA 0\% dan LAA 1\%. Pada P7, P8, dan P9, secara berturut-turut terjadi peningkatan penutupan luas luka 2,02x, $2,86 \mathrm{x}$, dan $1,81 \mathrm{x}$ dibandingkan jam ke-0 $(1,00 \mathrm{x})$ pada penambahan LAA $3 \%$. Sedangkan, pada perlakuan penambahan konsentrasi LAA 6\% menunjukkan peningkatan penutupan luas luka pada P7, P8, dan P9 secara berturut-turut 1,96x, 
$3,05 \mathrm{x}$, dan $1,54 \mathrm{x}$ dibandingkan jam ke-0 (1,00x) (Gambar 3).

Penambahan LAA sebagai suplemen antioksidan pada medium pertumbuhan ADSCs telah diketahui dapat menghambat proses penuaan ADSCs dengan menurunkan produksi ROS [28] dan meningkatkan proliferasi dan jumlah ADSCs [29]. Penurunan ROS pada ADSCs dapat menurunkan juga tekanan oksidatif yang dapat menunda penuaan sel [30]. Adanya peningkatan ROS dapat menjadi racun bagi ADSCs dan memacu terjadinya senesens dan apoptosis sel [31]. Sebaliknya, penurunan ROS dapat memicu persinyalan molekul dalam sel sehingga meningkatkan proliferasi dan migrasi ADSCs. Penurunan konsentrasi ROS ini dapat meningkatkan proses transduksi persinyalan ekspresi gen seperti Akt dan ERK1/2 yang telah diketahui dapat mengaktifkan tirosin kinase dan mengaktifkan tirosin fosfatase sehingga meningkatkan kemampuan proliferasi dan migrasi sel [32].

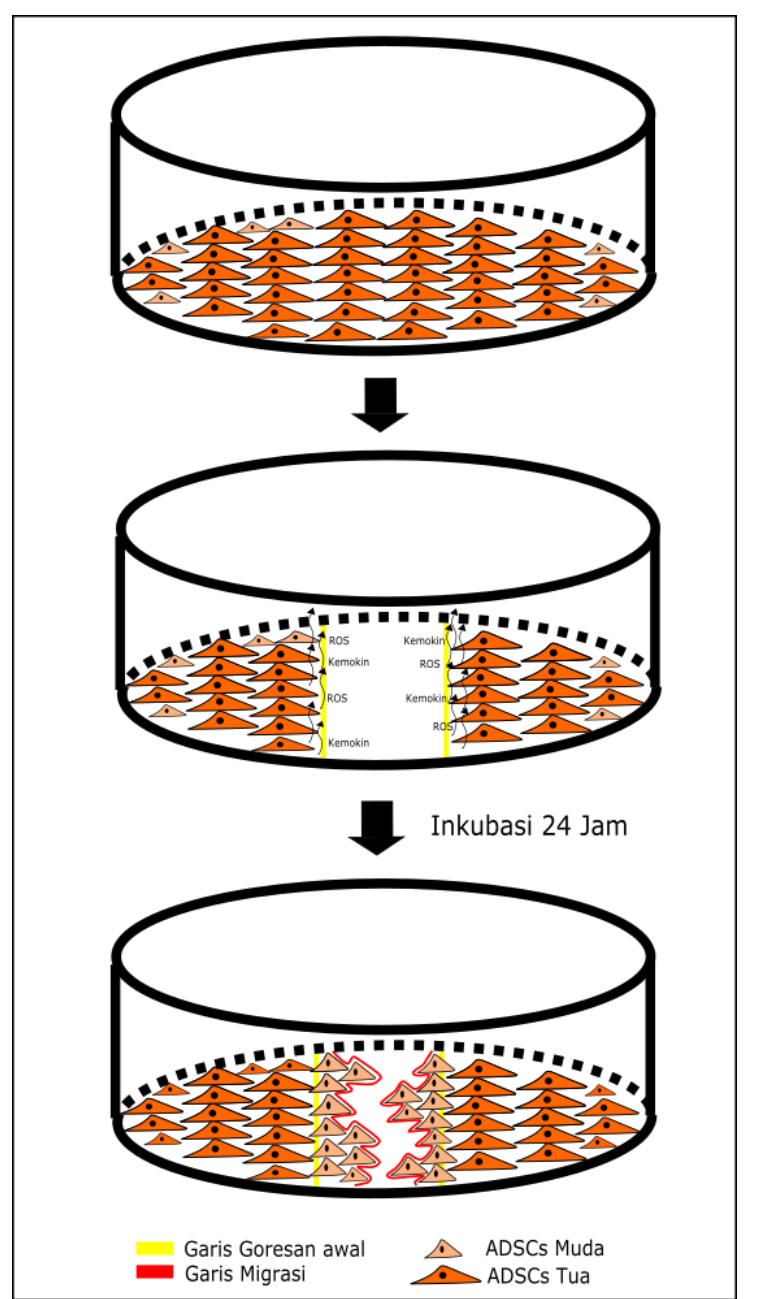

Gambar 4 Proses penutupan luka oleh aktivitas migrasi ADSCs selama 24 jam

\section{KESIMPULAN}

Adipose-derived stem cells (ADSCs) memiliki kemampuan migrasi sel yang optimal pada medium pertumbuhan rendah glukosa yang mengandung FBS dengan penambahan konsentrasi 3\% LAA dan $6 \%$ LAA dibandingkan dengan medium pertumbuhan dengan penambahan $1 \%$ LAA dan kontrol.

\section{REFERENSI}

[1] I. Rosadi et al., "In vitro study of cartilage tissue engineering using human adiposederived stem cells induced by platelet-rich plasma and cultured on silk fibroin scaffold," Stem Cell Research \& Therapy, vol.10, no.1, pp.1-15, 2019.

[2] Karina et al., "Diabetes mellitus type 2 reduces the viability, proliferation, and angiogenic marker of adipose-derived stem cells cultured in low-glucose anti-oxidantserum supplemented medium," Biomedical Research and Therapy, vol.6, no.3 pp.30733082, 2019.

[3] X. Fu, G. Liu, A. Halim, Y. Ju, Q. Luo, dan G. Song, "Mesenchymal Stem Cell Migration and Tissue Repair," Cells, vol.8, no.8, pp.784, 2019.

[4] G. F. Nicoletti, F. De Francesco, F. D'Andrea, dan G.A. Ferraro, "Methods and procedures in adipose stem cells: state of the art and perspective for translation medicine," J. Cell. Physiol, vol.230, no.3, pp.489-495, 2015.

[5] L. Mazini, L. Rochette, S. Amal, B. Admou, dan G. Malka, "Adipose Derived Stem Cells (ADSCs) Immunomodulation Impact on Skin Tissue Repair," Journal of Embryology \& Stem Cell Research, ISSN: 2640-2637, 2020.

[6] S. J. Zhang, X. Y. Song, M. He, dan S.B. Yu, "Effect of TGF- $\beta 1 /$ SDF-1/CXCR4 signal on BM-MSCs homing in Rat Heart of Ischemia/Perfusion Injury," Eur. Rev. Med. Pharmacol. Sci, vol.20, no.5, pp.899-905, 2016.

[7] A. C. Brignier dan A.M. Gewirtz. "Embryonic and adult stem cell therapy," $J$. Allergy Clin Immunol, vol.125, pp.S336-344, 2010.

[8] J. N. Barker dan J. E. Wagner, "Umbilical cord blood transplantation: current practice 
and future innovation," Crit Rev Oncol Hematol. vol.48, no.1, pp.35-43, 2003.

[9] P. A. Zuk et al., "Human adipose tissue is a source of multipotent stem cells," Mol Biol Cell, vol.13, no.12, pp.4279-4295, 2002.

[10] B. Lindroos, R. Suuronen, dan S. Miettinen, "The Potential of Adipose Stem Cells in Regenerative Medicine," Stem Cell Rev and Rep, vol.7, no.2, pp. 269-291, 2011.

[11] Y. Zhu, T. Liu, K. Song, X. Fan, X. Ma, dan Z. Cui, "Adipose-derived stem cell: a better stem cell than BMSC," Cell Biochemistry and Function: Cellular biochemistry and its modulation by active agents or disease, vol.26, no.6, pp.664-675, 2008.

[12] Hu J, Cheng D, Gao X, Bao J, Ma X, dan Wang $\mathrm{H}$, "Vitamin $\mathrm{C}$ enhances the in vitro development of porcine pre-implantation embryos by reducing oxidative stress," Reprod Domest Anim, vol.47, no.6, pp.873879, 2012.

[13] K. Fujisawa, K. Hara, T. Takami, S. Okada, T. Matsumoto, N. Yamamoto, dan I. Sakaida. "Evaluation of the effects of ascorbic acid on metabolism of human mesenchymal stem cells," Stem Cell Research \& Therapy, vol. 9, no. $1,2018$.

[14] I. Rosadi dan K. Moegni, "Perbandingan Kemampuan Migrasi Adipose-Derived Stem Cells Asal Manusia pada Berbagai Medium Pertumbuhan," Bioeksperimen, vol.6, no.1, pp.45-51, 2020.

[15] P. Y. Yue, E. P. Leung, N. K. Mak, dan R. N. Wong, "A simplified method for quantifying cell migration/wound healing in 96-well plates," J. Biomol. Screening, vol. 15, no.4, pp.427-433, 2010.

[16] K. Moegni et al., "Stromal vascular fraction (SVF) therapy for treatment of various diseases: delivering safety of the first patented svf technique in Indonesia," Cytotherapy, vol.21, no.5, 2019.

[17] M. Dominici et al., "Minimal criteria for defining multipotent mesenchymal stromal cells. The International Society for Cellular Therapy position statement," Cytotherapy. vol. 8, no.4, pp.315-317, 2006.

[18] N. Kramer et al., "In vitro cell migration and invasion assays," Mutation Research/Reviews in Mutation Research, vol.752, no.1, pp.10-24, 2013.

[19] C. C. Liang, A. Y. Park, dan J. L. Guan. "In vitro scratch assay: a convenient and inexpensive method for analysis of cell migration in vitro," Nature protocols, vol.2, no.2, pp.329, 2007.

[20] H. Büth et al., "Cathepsin b is essential for regeneration of scratch-wounded normal human epidermal keratinocytes," European Journal of Cell Biology, vol.86, no.11-12, pp.747-761, 2007.

[21] A. V. P. Bobadilla et al., "Local migration quantification method for scratch assays," $J$. R. Soc. Interface, vol.16, no.151, 2018.

[22] W. Wagner et al., "Replicative senescence of mesenchymal stem cells: a continuous and organized process," PloS One, vol.3, no.5, 2008.

[23] E. Fathi dan R. Farahzadi, "Isolation, Culturing, Characterization and Aging of Adipose Tissue-derived Mesenchymal Stem Cells: A Brief Overview," Brazilian Archives of Biology and Technology, vol.59, 2016.

[24] I. Rosadi et al., "The Effect of Human Platelet-Rich Plasma and L-Ascorbic Acid on Morphology, Proliferation, and Chondrogenesis Ability towards Human Adipose-Derived Stem Cells," Molecular and Cellular Biomedical Sciences, vol.3, no. $1,2019$.

[25] R. D. Horwitz dan Webb, "Cell Migration," Cur. Bio, vol.13, no.19 pp.756-759, 2003.

[26] G. Topman, O. Sharabani-Yosef, dan A. Gefen, "A standardized objective method for continuously measuring the kinematics of cultures covering a mechanically damaged site," Medical Engineering and Physics, vol. 34, no.2, pp.225-232, 2012.

[27] S. G. Park, J. H. Kim, Y. Xia, dan J. H. Sung, "Generation of reactive oxygen species in adiposederived stem cells: friend or foe?," Expert Opin Ther Targets, vol.15, no.11, pp.1297-1306, 2011.

[28] N. Liao et al., "Antioxidants inhibit cell senescence and preserve stemness of adipose tissue-derived stem cells by reducing ROS generation during long-term in vitro expansion," Stem Cell Res Ther, vol.10, no.306, 2019.

[29] L. Y. Sun et al., "Antioxidants cause rapid expansion of human adipose-derived mesenchymal stem cells via CDK and CDK inhibitor regulation," J Biomed Sci, vol.20, no.1, pp.53, 2013.

[30] E. H. Yao, Y. Yu, dan N. Fukuda, "Oxidative stress on progenitor and stem cells in cardiovascular diseases," Curr Pharm Biotechnol, vol.7, no.2, pp.101-108, 2006. 
[31] J. Case, D. A. Ingram, dan L. S. Haneline, "Oxidative stress impairs endothelial progenitor cell function," Antioxid Redox Signal, vol.10, no.11, pp.1895-1907, 2008.

[32] J. H.Kim, S. H. Park, S. G. Park, J. S. Choi, Y. Xia, dan J. H. Sung, "The pivotal role of reactive oxygen species generation in the hypoxia-induced stimulation of adiposederived stem cells," Stem Cells Dev, vol.20, no.10, pp.1753-1761, 2011. 